\title{
Doktora makalesi
}

Ögrr. Gör. Fatih Us

Haliç Üniversitesi, Mimarlık Fakültesi İç Mimarlık Bölümü

Danışman Yard. Doç. Dr. Saadet Aytıs

MSGSÜ, Mimarlık Fakültesi İç Mimarlık Bölümü

MSGSÜ, Fen Bilimleri Enstitüsü, İç Mimarlık Anabilim Dalı, İç Mimarlık Programı'nda yapılan "Mimari Mekanın Aktarımında Algılayıcı Hareketinin Önemi” başlıklı sanatta yeterlik tezinden oluşturulan bir makaledir. Makale metni 16.02.2009 tarihinde dergiye ulaşmış, 16.03.2009 tarihinde basım kararı alınmıştır. Makale ile ilgili tartışmalar 31.12.2009 tarihine kadar dergiye gönderilmelidir.

\section{Giriş}

Mimari mekânın görsel algısında hareket halindeki insanın algısı önemli bir yer tutmaktadır. Bu algı biçimi mimari mekânın aktarımında da kullanılması beklenen önemli bir faktördür. Bu çalışmada da; mimari mekânın aktarımında mekân içinde hareket eden insanın algısının önemi, nedenleri ve sonuçları ile birlikte ortaya konacak ve mekânın aktarımına bilgisayar teknolojilerinin desteği gösterilecektir.

\section{Tanımlar}

Mimari, birçok kaynakta "fonksiyon", “ teknik" ve "biçim" olarak üç ögede incelenmektedir. Bu ögelerden biçim ile mimari bütün görsel olarak algılanmaktadır. İnsanın mimari görsel algısını etkilemesi ve diğer ögeleri de içermesi nedeniyle biçim konusu ve onu oluşturan mekân kavramı bu çalışmanın önemli bir kısmını oluşturmaktadır.

\subsection{Mimari mekân:}

Mimarinin en önemli ögelerinden biri olan biçimin ana yapısını mekân oluşturmaktadır. Zevi, Giedion, Piaget, Pevsner, Rapoport, Lang ve Schultz gibi mimarlık ve mimarlığa paralel disiplinlerin kuramcıları, mekân kavramını geliştiren düşünce ve yaklaşımlarda bulunmuşlardır. Bu çalışmanın içerisinde bu bakış açılarından birkaçına değinilecektir. Mimarlık tarihçisi Nikolaus Pevsner (1963), mimarlığı 'mekân yaratma' eylemi olarak ifade etmektedir. Mimari mekân, insanın fizyolojik, psikolojik ve toplumsal gereksinmelerini karşılayan bir uzay parçası olarak tanımlanmaktadır (Norberg Schulz, 1971). Fransiz sosyolog ve felsefeci Henri Lefebvre (1991) ise mekânı, yaşanan, algilanan ve hayal edilen boyutlar olarak nitelemektedir. "Mimarlık, mekânı çerçeveleyen strüktürel elemanların genişliğii, uzunluğu ve yüksekliği ile oluşmaz. Bunlar vasıtası ile mekân tanımlanmaya çalışılır. Gerçekte mekân, içinde yaşanan ve hareket edilen, bu elemanlarla çerçevelenen, belirlenen boşluktur. Fakat bu elemanlardan oluştuğu anlamına gelmemelidir" (Zevi, 1993). Burada Zevi, hareketin önemini vurgulayarak mimari mekânı, içinde geçen yaşamsal
Mimari mekânın aktarımı için çeşitli teknikler kullanılmaktadır. Bu teknikler arasında çizim, maket, fotoğraf, sinemavideo, bilgisayar teknolojileri bulunmaktadır. İnsan gerçekte mekânı genellikle hareket halinde iken algılamaktadır. Bu nedenle mekânın aktarımında da algılayan hareketinin önemi büyüktür. Bu çalışmada mimari mekânın aktarım tekniklerini destekleyen algılayanın hareket faktörünün önemi günümüz teknolojileriyle birlikte ortaya konacaktır. Bunun için "mimari mekân", "alg1 psikolojisi” ve "görsel algı" gibi gerekli tanımlamalar yapılmakta, mekânın aktarım teknikleri ise "varolan mekânın aktarım teknikleri" ve "tasarlanan mekânın aktarım teknikleri” olarak iki sınıfa ayrılarak incelenmektedir. Daha sonra mimari mekânın görsel algısında algılayıcı hareketinin önemi belirtilmekte ve hareket faktörünün etkili olduğu mimari mekân tasarımlarından örnekler verilerek hareketin mekân aktarımında nasıl kullanıldığı anlatılmaktadır. Son olarak da mimari mekânın aktarımında algılayıcı hareketinin bilgisayar teknolojileri desteği ile nasıl gerçekleştirilebileceği gösterilmektedir.

Summary:

Various techniques are used for the representation of the architectural space. These techniques include drawing, modelling, photograph, cinema-video and computer technology. A human being usually perceives a space as if it was moving. That is why, in space representation processes, perceiver's movement has an important place. In this article, importance of the perceiver's movement, which supports the space representation techniques, will be put forward with the recent technology's help. To serve this purpose, necessary terms are

being introduced, such as; architectural space, perception, and visual perception. It is also analyzed firstly as "the present space's representation techniques" and secondly as "designed space 's representation

techniques". Then, the importance of the perceptive movements in architectural space 's visual perception will be mentioned. Also, examples will be given about the factor of movement in designing architectural spaces. Last but not least, how to use the computer technology to show the perceptive movement in representation the architectural spaces will be explained. Anahtar Kelimeler: mimari mekân, görsel alg1, hareket Keywords: architectural space, visual perception, movement 
deneyim ile anlamlandırmaktadır. $\mathrm{Bu}$ tanımlar sonucu mekânı tanımlayan ögeler şöyle sırala-nabilir: Boşluk ve sınır, hareket ve zaman, 1şık. Bu çalışma içinde mekânı tanımlayan bu özelliklerden hareket önemli yer tutmaktadır.

\subsection{Algı psikolojisi:}

Algı, insanın çevresiyle olan iletişim sürecinin temelini oluşturan bir olgudur. Algı kuramlarına değinmeden önce farklı görüş açıları ile yapılmış algı tanımlamalarını gözden geçirmek yararlı olacaktır:

Alg1; "Bir şeye dikkati yönelterek o şeyin bilincine varma, idrak (ruh bilimi)"tir (URL-1, 2008).

Psikolog Morgan (1995) ise algı1, duyumları yorumlama, onları anlamlı hale getirme süreci olarak tanımlamaktadır. Morgan algıyı, duyum süreci ile ilişkilendirmektedir.

Genel Psikoloji alanında algı ile ilgili geniş kapsamlı çalışmaları bulunan Atkinson'a göre alg1; "çevredeki uyaran örüntülerinin organizasyonu ve yorumlanması süreci” dir (Atkinson vd., 1995). Sonuç olarak algılama, 'duyularla farkına varma' ve 'akıl yoluyla bilgi alma' olmak üzere iki anlamı da içine almaktadır (Baymur, 1994).

\subsection{Görsel algı:}

Mekân ile kurulan algısal ilişkide tüm duyular, mekândan edinilen algıyı ve imajı etkiler. Ancak çevresel algı açısından insan duyularından birinci derecede görme duyusu, sonra işitme duyusu önemlidir. Görme duyusu, bütün duyular içinde en karmaşık olanıdır. Görme duyumunun gerçekleşmesi için mutlaka 1 şı gerekmektedir. Görme, 1şık olarak algılanan dalga boyunun göz aracılığı ile beyne iletilme sürecini kapsamaktadır.

“Görme, görünür spektrumdaki elektromanyetik dalgaların, göz merceği

ve ağ tabakadaki (retina) alıcılara odaklanması, buradaki ışığa duyarlı pigmentlerin çözülmesi ve bunun beyne ulaşan sinir akımını başlatması ile oluşur" (Sekuler, 1994).

Çevreden alınan bilgilerin yaklaşık yüzde seksenden fazlası göz aracılığı ile algılanmaktadır (Berger, 1998). Dolayısıyla görme duyusu, mekânın algılanmasında en önemli rolü üstlenmektedir.

\section{Mimari mekanın görsel algısı ve aktarım teknikleri}

Mimari mekânın tasarımında, kullanımında ve değerlendirilmesinde görsel alg1 önemli bir fonksiyon üstlenmektedir. Bu çalışmada da mekânın aktarım teknikleri görsel algılama yönünden ele alınacaktır.

Mimari mekânın aktarımı ile kastedilen ise varolan ya da tasarlanan bir mekânı tasarımcının kendisine, kullanıcıya ya da farklı bir amaçla kullanması için üçüncü şahıslara özel tekniklerle sunulması ya da arşivlenmesi yöntemidir.

Mimari mekânın aktarım tekniklerini incelemeden önce aktarım tekniklerinin gelişimine bakılacak olursa en eski çizimlerden biri M.Ö. 2100’de Bahari'de bir Mısır tapınağının önünde bulunan peyzaj planı çizimi dikkat çeker. Burada yapılmış çizim günümüzdeki plan çizim tekniğine benzemektedir (Porter, 1979). Bilinen en eski aktarım teknikleri plan çizim tekniği ve makettir. Günümüzde çeşitli bilgisayar programlarında da kullanılan birbirini dik kesen, eşit aralıklardaki ızgara sistemli çizim alanından yararlanma da çok eskiye dayanmaktadır. Vitruvius (1990), yapının plan biçiminde gösterimine ichnographia, cephe görünüş biçimine orthograpia ve üç boyutlu gösterimine de scenographia adını vermektedir. Buradan da anlaşıldı $\breve{g ̆}_{1}$ üzere 
geometride perspektif bilgisi antik döneme kadar gitmektedir.

Ortaçă̆ mimarları mimari aktarım aracı olarak ahşap maketleri kullanmışlardır. $\mathrm{Bu}$ maketler, sunum ve strüktür testleri için yapılmaktaydı. Çizim tekniklerinin ise binanın tümü için değil bir kısmının çözümlemesi için kullanıldığı söylenmektedir. Bu dönemde mimarlar inşaat ortamını tasarım ortamı olarak görmüşlerdir.

15. yüzyılda perspektifin tekrar keşfedilmesi, mimari mekân aktarım tekniklerinin en önemli dönüm noktalarından birini oluşturmaktadır. Perspektif tekniğini ilk kez kullanan ve yayılmasını sağlayanlar arasında Brunelleschi ve Alberti bulunmaktadır. Perspektif ile birlikte mimarlar mekânları resimsel mekânlar biçiminde tasarlamaya başlamışlardır. Plan, kesit, cephe ve perspektifin birlikte kullanılması Rönesans'la birlikte başlamıştır. Rönesans'ta kullanılan maket yöntemi ise kütle boşluk oranlarının anlaşılmasında çı̆̆ır açan bir yöntem olarak önem kazanmıştır.

16. yüzyılda mikroskobun ve teleskopun bulunuşu ile perspektifteki kaçış noktaları mekânın dışına doğru çıkmıştır.

18. yüzyılda Aydınlanma dönemi ile birlikte aktarım tekniklerinde iki önemli gelişme olmuştur. Bunlardan biri Fransız matematikçi Gaspard Monge'un üzerinde çalışmalar yaptığı ve geliştirdiğ geometridir. Tasarı geometrinin ana ilkesi, dik izdüşüm metodudur. Bu metot ile iki boyutlu kağıt üzerine üç boyutlu olan cisimler ölçekli olarak çizilebilmektedir. İkinci önemli gelişme ise bu dönemde kağıt üzerinde aktarılan düşüncelerin de mimari ürün gibi görülmesidir. Bu durum özellikle ütopik projelerde görülmektedir. 19. yüzyılda mimarlığa giren bir başka aktarım tekniği de aksonometridir.
Aksonometri, bir cismi üç boyutlu olarak gösteren bir geometrik çizim türü; paralel izdüşümle elde edilen perspektif biçiminde tanımlanmaktadır.

Aksonometride göz sonsuzda bulunmaktadır (Hasol, 1998). Aksonometri, kişinin kendi bakış açısına göre bir aktarım tekniği değil, soyut ölçüler sistemi kullanılan bir tekniktir. Bu teknikte gözün yerini aklın belirleyiciliği almıştır.

20. yüzyılda ise Modernizm ile birlikte mimariye bir çok aktarım tekniği girmiştir. Bunlara kolaj ve fotoğraf tekniğinin bir arada kullanıldığı kompozisyonlar, özellikle ütopik tasarımların resimsel çizimleri örnek gösterilebilir. Bu dönemde mimari akımlara ya da kişisel bakış açısına göre aktarım teknikleri değişmiştir. O zamana kadar kullanılan aktarım teknikleri farklı biçimlerde kullanılmaya başlanmıştır.

Modern sonrası dönemde, mekânın deneyimlenmesi, dolayısıyla da zaman ve hareket faktörü, mekânın aktarımında belirleyici olmuştur. Mekânda yaşayış belirlenmekte ve seri eskizler yapilmaktadir. 1960'lı yıllarda bilgisayarın mimariye girmesi ile birlikte mimari mekânın aktarımında köklü değişimler başlamıştır. Bilgisayar programları ile 2 boyutlu çizimler kolay ve hızlı bir biçimde yapılabilmekte, gerçekçi görüntülere yakın 3 boyutlu görüntüler alınabilmekte, animasyon tekniği ile bir mekân içinde gezilebilmekte ve sanal gerçeklik ile sanki o mekânın içindeymişiz hissi verilebilmektedir.

\subsection{Varolan mekânın aktarımı}

Bu çalışmada varolan mekânın aktarımı, beş başlık altında incelenecektir:

1. Çizim; Eskiz, Perspektif, Rölöve, 2.

Maket, 3. Fotoğraf, 4. Bilgisayar

Teknolojisi, 5. Sinema ve video

84 Sayı 7, Mayıs 2009 
Çizmek, düşünceleri ve izlenimleri görselleştirerek somut hale getirmektir. İnsanoğlunun varoluşundan bu yana çizgi, dilden daha önce kullanılmaya başlanmıştır. İnsan, avlanmak, barınak yapmak, düşüncelerini anlatmak gibi

Resim: I

M. Türkmen,Anadoluhisarı (inceoğlu, 1995) Resim:2 Ayasofya maketi (URL-2, 2008) Resim: 3 Guggenheim Müzesi, Bilbao, Ispanya, 1991-97, Frank O. Gehry, Randy Jefferson ve proje grubu (Dal Co, Forster, 1998)
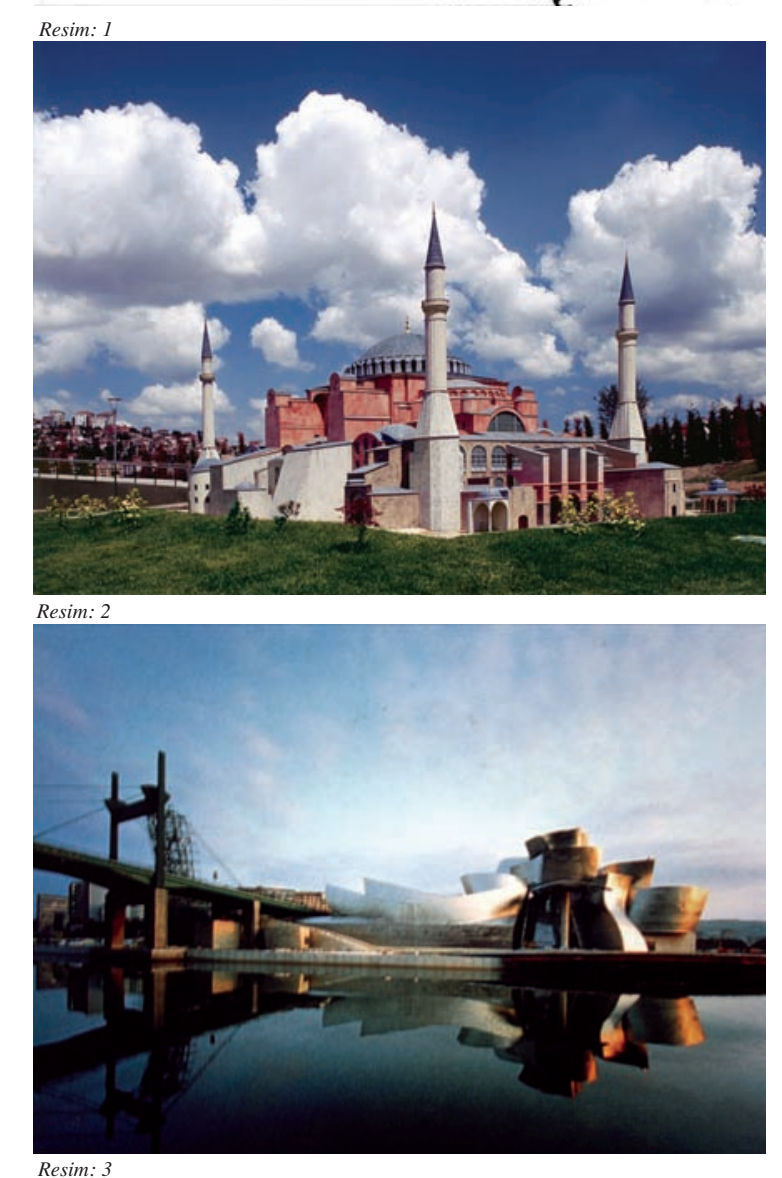

birçok ihtiyaç için çizgiyi kullanmıştır. Mağaralardaki çizimler buna örnek olarak gösterilebilir. Çizim, mimari mekânın aktarım tekniklerinin başında gelmekte, diğer tekniklerin temelini oluşturmaktadır. İnsan, düşüncelerini günlük hayatta ve edebiyatta yazı ile anlatırken mimarlıkta çizgi ile anlatmaktadır. Bu anlatım eskiz (Resim 1.), perspektif ve rölöve biçiminde olmaktadir.

Mimari maket; inşa edilmiş veya edilecek olan binanın uygun bir malzemeden, belli bir ölçekte küçültülerek yapılmış gerçek (üç boyutlu) ifadesidir. Varolan mimari mekânın maketi genellikle tarihi yapıların ziyaretçilere tanıtımında müzelerde ya da bitmiş projenin müşteriye sunumu aşamasında kullanılır. Örneğin Türkiye ve Osmanlı coğrafyasından seçilmiş eserlerin 1/25 ölçekli maketlerinin yer aldığg1 Türkiye'nin ilk minyatür parkı olan "Miniatürk"te Ayasofya'dan (Resim 2)

Kubbet-üs Sahra'ya kadar bir çok maket örneği bulunmaktadır.

Fotoğraf, günümüzde varolan mimari mekânın aktarım tekniklerinden en yaygın olanıdır. Gerek turistik gezilerde, gerekse mimari gezilerde kullanımının rahat olması nedeniyle bir mekânın aktarımı ya da arşivlenmesi için fotoğraf tercih edilmektedir. Mimaride fotoğraf, bir projenin anlatımında ve detaylı bir biçimde incelenmesinde mimarlık kitaplarında, dergilerinde, vb. kullanılmaktadır (Resim 3).

Bilgisayar teknolojileriyle varolan bir mekânın aktarımı teknik resim kurallarına göre iki boyutlu ve üç boyutlu çizim biçiminde; render; animasyon olarak; sanal gerçeklik ve sanal turlar biçiminde yapılabilmektedir. Buna örnek olarak Le Corbusier'in Villa Savoye binasının bilgisayarda modellenerek alınan renderı gösterilebilir (Resim 4). Burada 1928-1929

Sayı 7, Mayıs $2009 \mid 85$ 


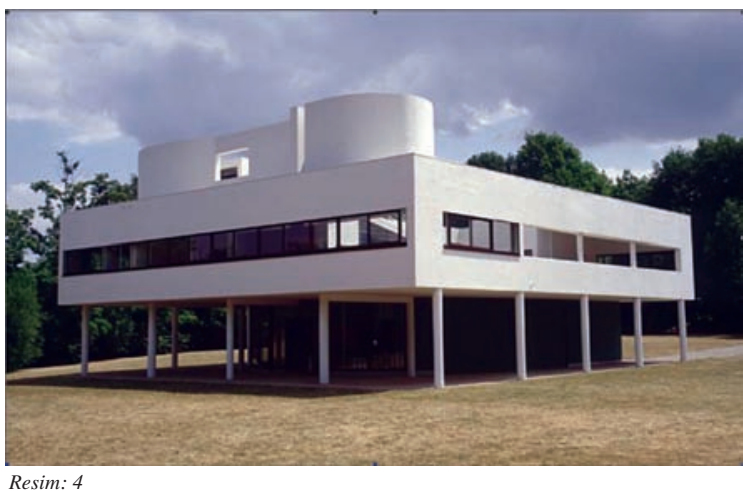

tarihlerinde yapılmış olan bir yapının, kitaplardan alınan ölçülü çizimleri yardımiyla 3 boyutlu modellemesi bilgisayar programında yapılmıştır. Yapılan bu model ile o yapıya daha sonra istenildiği yerinden bakılabilme ve o yapının mimari özelliklerini bir başkasına kolay bir biçimde anlatabilme imkânı kazanılmıştır. Sinema ve mimarlık arasındaki sıcak ilişkiye bir başka yorum getiren mimarlık tarihçisi Uğur Tanyeli (2001) bu etkileşimin üç tane yol izlediğini belirtmiştir.

Birinci yol, sinemanın inşa edilmemiş ve gerçeklik düzleminde kullanılmayan bir sanal mimarlık alanı tanımlaması biçiminde oluşmaktadır.

İkincisi, sinemanın 'gerçek' mimari mekânları kendi sanal evreninde yeniden üretmesi ile somutlaşmaktadır. Üçüncü Resim: 5

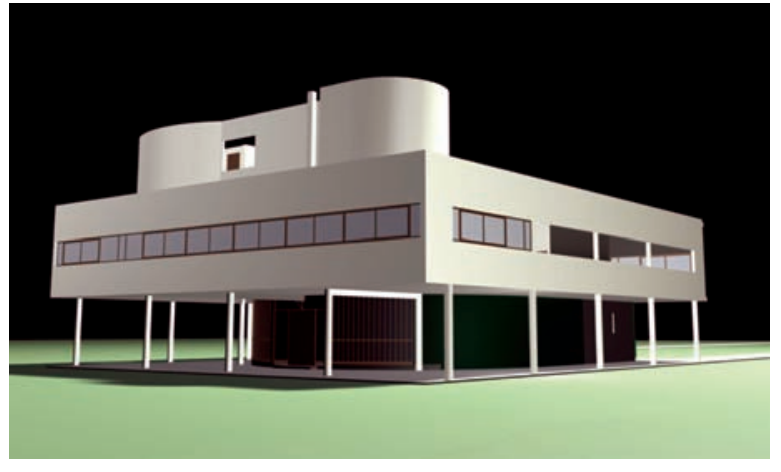

yolda ise sinema kendi olay kurgusu içinde bir kişilik olarak mimari ve/veya mimarlık etkinliğini konu almaktadır. Mimarinin önemli bir öge olarak işlendiği sinema filmlerine örnek olarak Playtime, The Fountainhead ve My Architect filmleri gösterilebilmektedir. Bu filmlerin kurgusunda kullanılan mekânlar ön plana çıkmakta ve ana temayı oluşturmaktadır. Playtime filmi (Resim 5), taşralı Mr. Hulot'un Paris şehrine ve modernizme ayak uydurma çabalarını komik bir üslupla sergilemektedir.

\subsection{Tasarlanan mekânın aktarımı}

Bu bölümde de tasarlanan mimari mekânın aktarım teknikleri üç başlık altında incelenmektedir: 1. Çizim: Eskiz, Teknik Çizim (Teknik Resim), Perspektif, 2. Maket, 3. Bilgisayar Teknolojileri

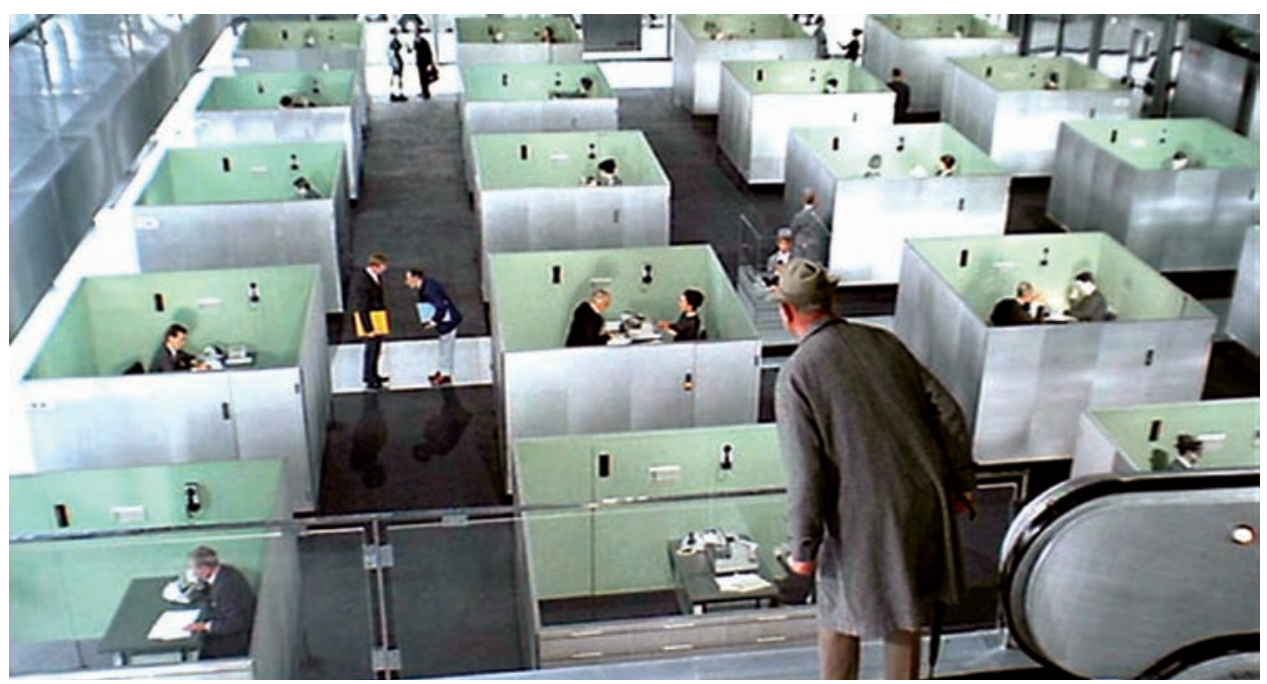

86 Sayı 7, Mayıs 2009 
Tasarım aşamasında yapılan eskiz, düşünülen mekânın temel niteliklerinin mimari bir dille aktarılması sonucunda ortaya çıkmaktadır. Beklenen ürünün ana hatlarını ifade etmektedir. Bu eskizlerde aranılan ve anlatılmak istenen bir ana fikirdir (Resim 6).

Maketler, konuyu tanıtmak ve analiz etmek, form geliştirmek, parçaları
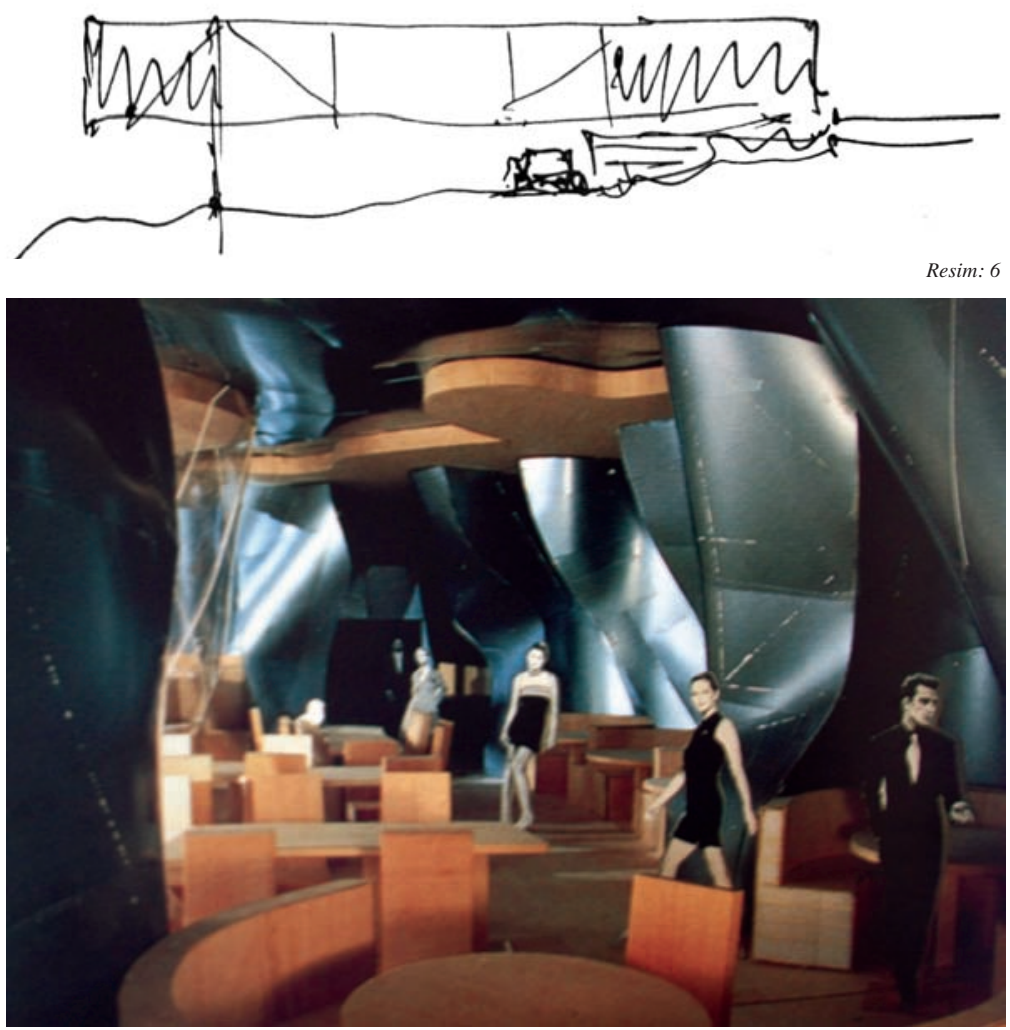

Resim: 6

birbirine bağlayarak bütünü oluşturmak Mies van der Rohe'un Cam Ev Eskizi (Inceoğlu, 1995)

Resim:7 Kafeterya maketi, New York, 1997-, Frank O. Gehry, Randy Jefferson ve proje grubu (Dal

Co, Forster, 1998)

Resim: 8

Nationale-Nederlanden Binasi, Prag, Cek Cumhuriyeti, 1992-96, Frank O. Gehry, James $M$. Glymph ve Proje Grubu (Dal Co, Forster, 1998) gibi birçok amaca hizmet etmektedir. $\mathrm{Bu}$ aşamada yapılan modellere "fikir maketi” denmektedir (Resim 7).

1990'l1 yıllarda bilgisayar teknolojilerinin hızlı gelişmesi ile birlikte bilgisayar, tasarım geliştirme amacıyla kullanılmaya başlanmıştır. Günümüzde bilgisayar teknolojileri mimarlık ortamında hem tasarımı geliştirme hem de tasarımın aktarımı için kullanılmaktadır. Tasarımcıların kullandı ğı çeşitli bilgisayar programları bulunmaktadır. Bunların içinde en yaygın olanları tasarım, çizim ve detaylandırma imkanı tanıyan AutoCAD, modelleme, kaplama ve canlandırma yazılımı olan 3ds MAX'tir. Bunların dişında ArchiCAD, Revit Architecture, Cinema 4D, Allplan, Catia gibi çeşitli yazılımlar da sıklıkla kullanılmaktadır. Bu programlardan özellikle Catia'yı tasarımlarında kullanan Frank O. Gehry, genellikle bilgisayar programlarını, eskizi ve maketi birlikte kullanmaktadır (Resim 8).

\section{Mimari mekanın görsel algısında hareketinin önemi}

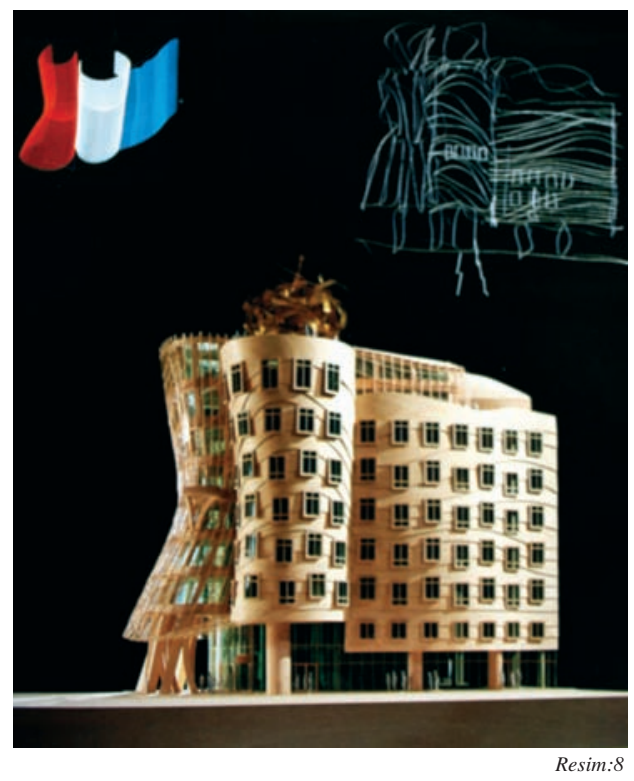

Mekân aktarım tekniklerinden sinema ve bilgisayar teknolojileri dişında kalanların hemen hemen hepsi donmuş görüntülerden oluşmaktadır. Oysa ki, insan gerçekte böylesi donuk bir algıya sahip değildir. Mekânlar insanlar için tasarlanmakta; insanlar da bu mekânlarda heykeller gibi hareketsiz bir noktada durmayıp sürekli hareket etmektedirler. Kendileri hareketsizken bile gözleri hareket etmektedir. $\mathrm{Bu}$ bölümde insanın mekân içinde hareket sınırları ve mekânın 
aktarımındaki etkileri incelenmektedir. İnsan ve mimari arasındaki ilişkide sürekli bir karşılıklı etkileşim mevcuttur. Bu etkileşim nesnelerin insana gönderdiği uyarıcıların insan tarafından algılanması ile gelişmektedir.

Mimari bütünün ana öğelerinin insanla ilişkisinin kendi özellikleriyle ilgili olmasının yanında biçim öğesi, gönderdiği uyarıcılarla fonksiyon ve teknik öğelerinin özelliklerinin ve karakterlerinin insanla ilişkisi için bir bağ oluşturmaktadır. Mimari bütünün algısında biçimin, aracı bir öğe olduğu anlaşılmaktadır. Sonuç olarak mimari bütün biçim aracılığı ile algilanmaktadır (Resim 9).

\subsection{Mimari mekânın görsel} algısında hareket faktörü
Hareket, mimarinin oluşumunda birlikte etkin bir faktör olmasına karşın ciddi boyutta ele alınması 20. yüzyıl başlarında olmuştur. Mekân, biçim, işlev ve teknik ögelerin birleşiminden oluşan mimarlık, zaman ve mekân içinde hareket yolu ile algılanır (Ching, 2007). Hollandalı mimar Hoogstad da (1990), mekânın sadece içinde gezilerek algılanabileceğini belirtmiştir. Norberg Schulz (1971), insanın mekânın merkezinde olduğunu ve mimari mekânın yönelimlerinin insan bedeninin hareketleri ile değiştiğini belirtmektedir. Dolayısıyla mimari mekân insan hareketlerinden bağımsız olarak düşünülmemelidir. Mimari mekânın görsel algısında deneyim ve buna bağlı olarak da hareketin önemi büyüktür. Mekânın içinden geçmek,

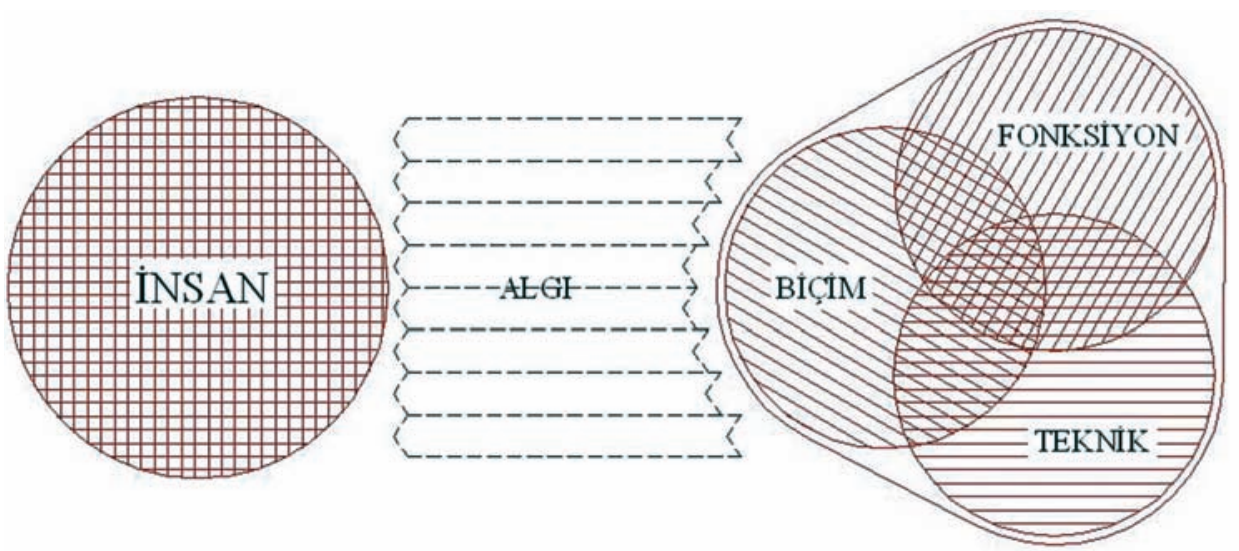

Resim: 9

Algıdaki hareket, nesnenin hareketi, insanın hareketi ve hareket etmeyen birbirinden ayrı uyaranların art arda algılanmasıyla oluşan hareket olarak sınıflara ayrılabilir. Nesnenin hareketi çevredeki birçok ipucuyla algılanabilir. Buna örnek olarak nesne hareket ettikçe zeminin bir kısmı kapanırken, yeni bir kısmının görülmesi gösterilebilir (Atkinson vd., 1995).

Psikolog James J. Gibson, hareketli görüntünün durağan bir görüntüden daha çok bilgi verdiğini belirtmektedir. mekânı ziyaret etmek, mekânda dans etmek, görülemeyenin ayırt edilmesine imkân sağlamaktadır. Yaklaşmak, uzaklaşmak, yukarı çıkmak, aşağı inmek, içeri girmek, dışarı çıkmak o mekân içinde görmek, duymak, hissetmek, koklamak ve dokunmak istediğimizi kendimiz için organize etmeye davet eden faaliyetlerdir (Meiss, 1990). İnsan, gözlerini, başını ve vücudunu hareket ettirerek çevresindeki küçük detayları algılar. Deneyimle beraber çevresindeki nesnelerin daha küçük detaylarını ve geniş çaplı ilişkilerini
Resim:9

insan ve mimari ögelerin ilişkisi (Erkman, 1973)

Mimari mekânın görsel algısını etkileyen faktörlerin bazıları şöyle siralanabilir: Hareket, Bakış Af̧ısı, Zaman, ölçü ve ölşek, Işık, Form, Renk ve Doku. 


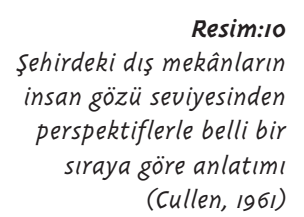

(cullen, 1961)
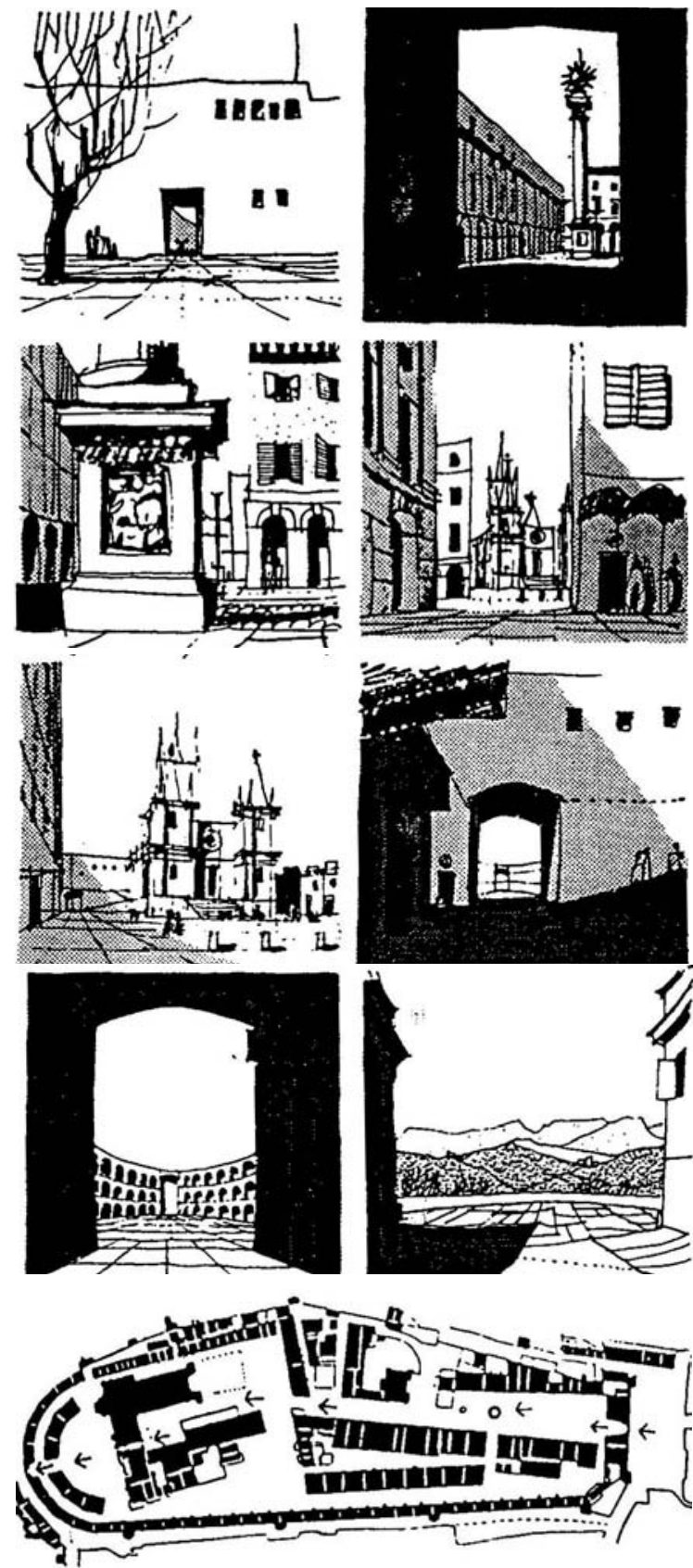

Resim: 10

saptayabilir (Lang, 1987).

İnsan mekâna farklı bakış açılarından bakarak, içinde gezerek ve zaman geçirerek algılamakta böylece orayı yaşamaktadır. İnsan mekân içinde hareket halindedir. Hareket, yön, hız ve zaman parametrelerine bağlıdır. Hoogstad (1990) mimari ve hareket arasındaki ilişkiyi şöyle belirtmiştir: "Amacım, hareketin gerçeğini ortaya koymak olsa da, ulaşılan nokta, bizi mimarinin egzotik güzelliğine götürmektedir".

Görsel çevrenin algılanması zaman gerektiren dinamik bir süreçtir. İnsan çevre içinde dolaşırken pozisyonu ve nesnelere olan mesafesi değişir. Her yeni pozisyonunda çevresindeki nesneler arası ilişkilere dayalı görsel nitelikler de değişir. İnsanın, hareket süresinde devamlı değişen görsel nitelikleri kavraması hareketinin hızına bağlıdır (Yürekli, 1977). Kentsel tasarımcı Gordon Cullen'in (1961) çizimlerinde, mekânın algılanışında hareket ve zaman faktörünün etkisi görülmektedir (Resim 10). Planda görülen baştan sona yürüyüş aksındaki insan gözünden bakışlar sıra ile gösterilmektedir. Plandaki her bir ok işareti bakışı simgelemektedir.

Le Corbusier binanın değerinin yürüyerek anlaşılabileceğini belirtmekte; yürüdükçe bakış açılarının değiştiğini vurgulamaktadır. Corbusier'in bu görüşü mimarinin sunum aracının fotoğraf ve çizim yerine film olması için temel kaynak oluşturmaktadır

(Benton, 1997).

Resim 11'de Villa Savoye'nin iç mekân görüntüleri bulunmaktadır. Mekân içinde insan hareket ettikçe çok farklı bakış açıları ortaya çıkmaktadır. Bunu aktif bir hale getirmek için Corbuiser, rampa başta olmak üzere geniş pencere açıklıklarından yararlanmıştır.

Steven Holl, Stretto Evi örneğinde olduğu gibi projelerinin mimarisinde akışkan mekânlar kullanmaktadır (Resim 12). Storefront Sanat ve Mimarlık Galerisi'nde iç mekânda, hareket halindeki kullanıcıya duvarlarda açılan yarıklardan gelen doğal 1ş1klarla sürpriz görünümler oluşturmaktadır (Resim 12). Kiasma Helsinki Çağdaş Sanatlar Müzesi'nde ise, devamlı değişen

Sayı 7, Mayıs 20098 


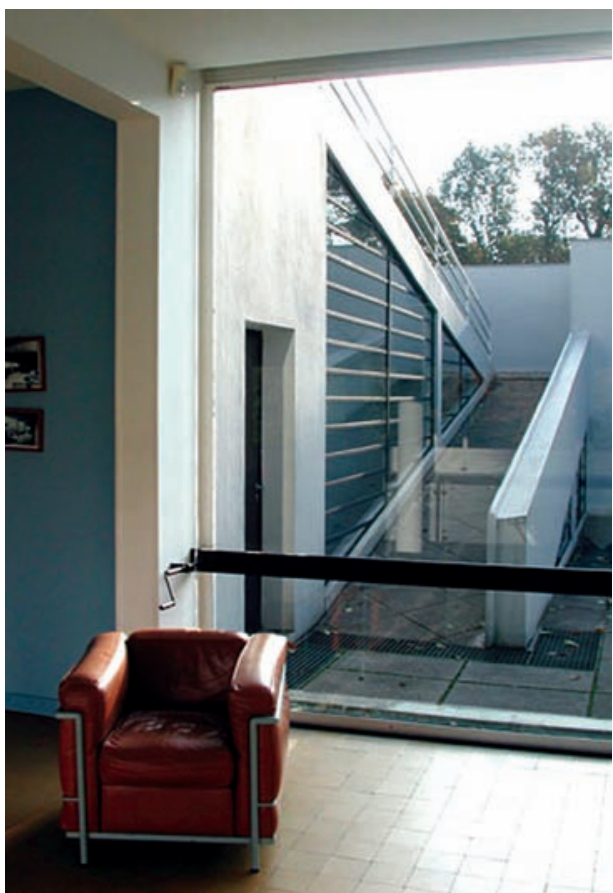

ve kesintiye uğramayan perspektifler açılmaktadir.

Yukarıda mimari mekânda hareket

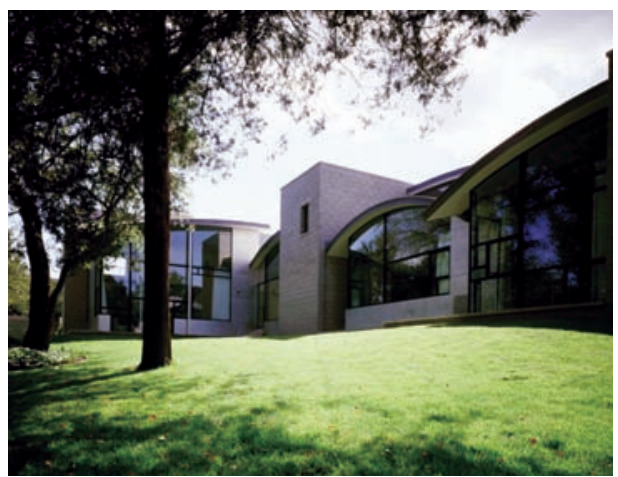

Resim: 12-a

faktöründen etkilenen birkaç mimari

örnek verilmiştir. Mekânın algılanmasında insanın hızının ve algılama süresinin önemi büyüktür. Araba ile geçerken şehri algılamakla, yürüyerek geçerken algılamak arasında büyük farklar vardır. Bunun bilincinde olan mimarlar sadece statik bakış açısından bakarak tasarım yapmazlar. Farklı açılardan güzel görüntüler alacak biçimde tasarımlar gerçekleştirirler. İnsanın mekânda dolaşırken algıladığı görüntüler

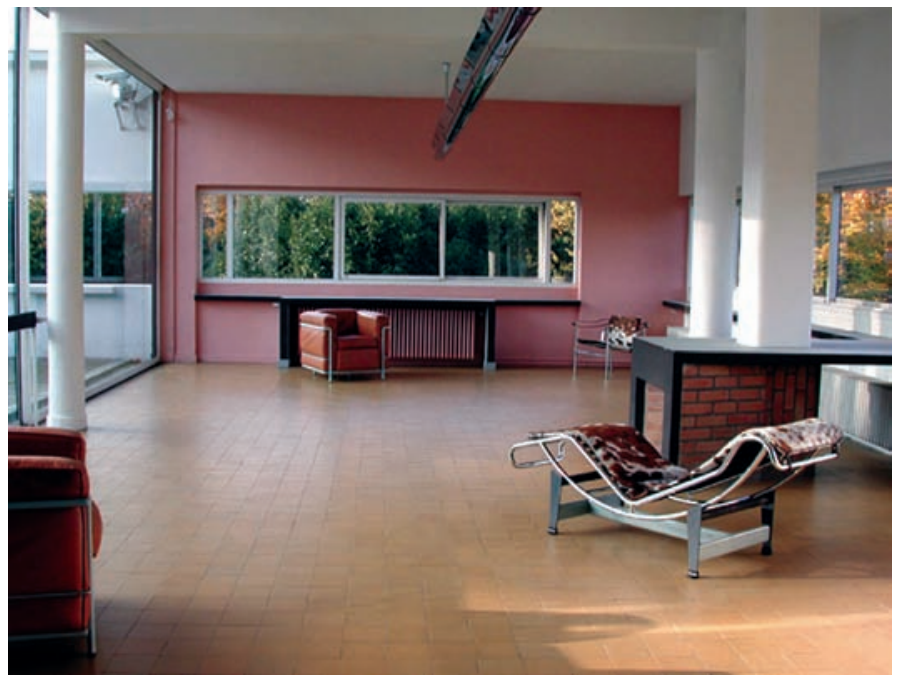

Resim: 11

bir araya geldiğinde mekân ortaya çıkmaktadır. Dolayısıyla mimar, bu görüntüleri nasıl bir araya getirebileceğini düşünmekte ve insanın o mekân içindeki deneyimini tasarlamaktadir.

Algılayıcı, mekân içinde hareket

Resim: II

Villa savoye yapisindan if görünüşler, Le Corbusier, 1929 (URL-5, 2008, URL-6, 2008)

Resim: 12 ( $a$ ve b) Stretto Evi, storefront Sanat ve mimarlik galerisi, Steven Holl (URL7, 2008, URL-8, 2008)

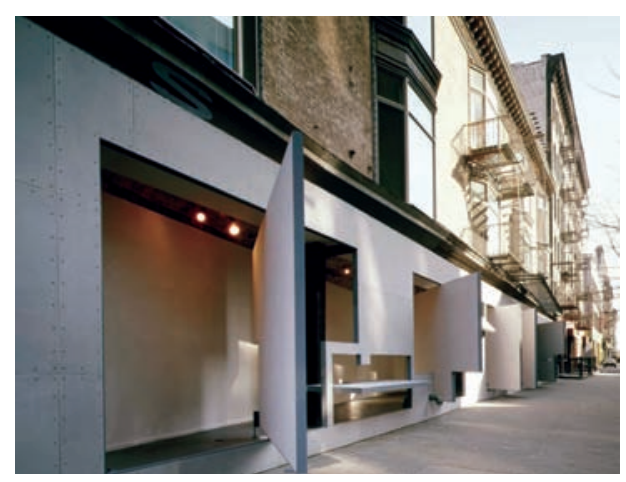

Resim: 12-b

ederken, bedeninin, başının ve gözlerinin hareketi görsel çevrenin hareketi ile pekişmektedir. Yukarı, aşağı, yana bakabilmekte ve görüş alanı sınırları içerisinden bilgi toplayabilmektedir (Porter, 1997).

Sonuç olarak beden ve deneyimler, yaşanılan binalarla sürekli iletişim halindedir. Algılar değişmekte, deneyimler değişmekte ve dolayısıyla binalar değişmektedir. 
Resim: 13 Düssey düzlemde görüs alanı (Panero, Zelnik, 1979)

Resim: 14

Yatay düzlemde görüş alanı (Panero, Zelnik, 1979)

Resim: I5

Düssey düzlemde başın hareketi

(Panero, Zelnik, 1979)

Resim: 16

Yatay düzlemde başın hareketi

(Panero, Zelnik, 1979)

\subsubsection{Algılayıcı hareketleri}

İnsanın hareketlerini anlayabilmek için öncelikle insanı tanımak gerekmektedir. Biyolojik varlık olarak insanı öğrenmek için anatomi, fizyoloji, psikoloji ve bunların alt dalları olan antropometri ve ergonomi disiplinleri incelenebilir. Ancak bu çalışmanın konusunu "mekânın görsel algısında algılayıcı hareketi”nin oluşturmasından dolayı insanın mekânı algılarken yaptığı temel hareketler incelenecektir.

Görsel algıyı etkileyen insanın mekân içinde yaptığg hareketler iki kısımda ele alınmaktadır:

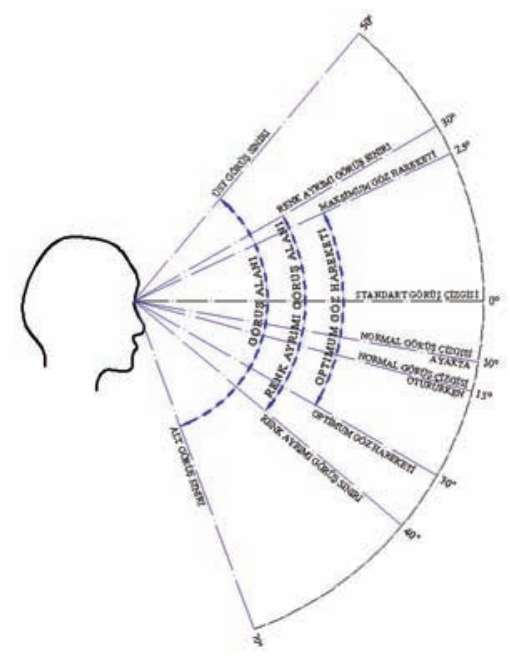

Resim: 13

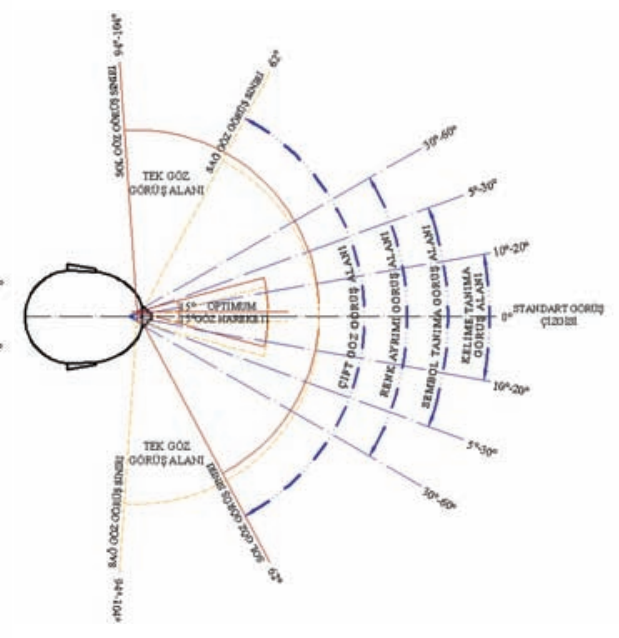

Resim: 14

- Göz ve Baş Hareketleri

- Beden Hareketleri

Mekânı kullanan bir insan, çevresinin görsel algısı esnasında temel olarak göz ve başını hareket ettirir. Bunu yaparken bedenini de kullanmaktadır. Statik görüş alanı diyagramında da görüldüğü gibi insanın bakışları göz yapısı nedeniyle aşağıya doğrudur (Resim 13.). Yukarı doğru bakmak için boynunu çevirmesi ve kasların hareket ettirilmesi gerekmektedir. İnsanın düşey ve yatay düzlemde görüş alanı Resim 13. ve Resim 14'de görülmektedir. Başın düşey düzlemde maksimum hareket sınırı öne doğru $40^{\circ}$, arkaya doğru $50^{\circ}$; yatay düzlemde maksimum hareket sinırı ise $55^{\circ}$ ' dir (Resim 15. ve Resim 16). İnsan, başın maksimum hareketlerini güç kullanarak yapabilmektedir.

Beden hareketleri, üst ve alt beden hareketi diye iki bölümde incelenebilir. Üst beden, yani gövdenin sağa ve sola dönüşü $40^{\circ}$ civarındadır. Öne ve arkaya eğilme hareketi ise sınırlı derecede yapılmalıdır.

İnsanın ayakta normal duruşu esnasında dizleri gergin bir biçimdedir. Ancak, otururken ya da yatarken dizler $70^{\circ}-130^{\circ}$ açıları arasında en rahat pozisyondadır.

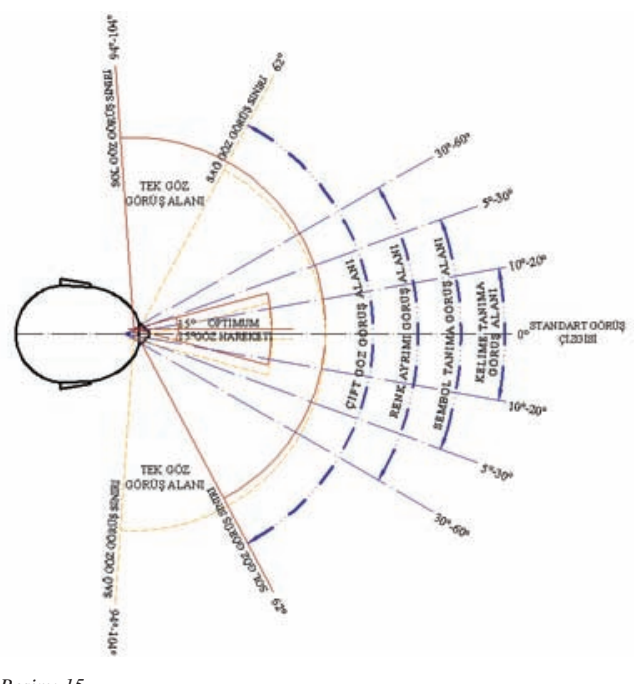

Resim: 15

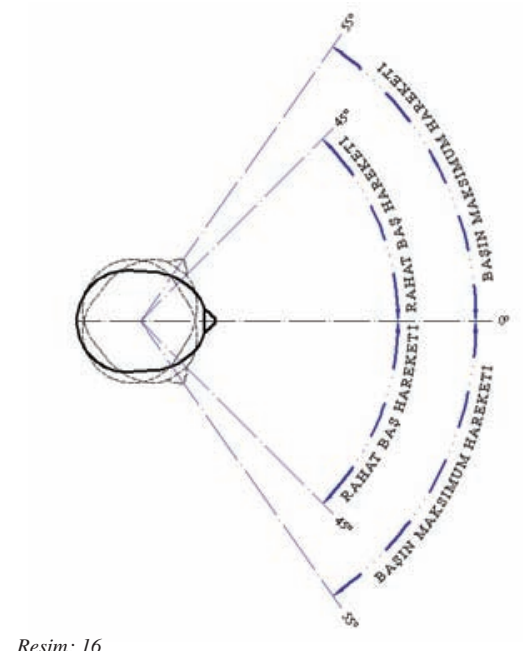

Resim: 16

Sayı 7, Mayıs 20099 
Kalça eklemi, omuz eklemi ile kıyaslandığ zaman hareketlerinin önemli ölçüde sınırlı olduğu görülmektedir (URL-9).

\subsubsection{Mimari mekânda algılayıcının hareketi}

Algılayıcı hareketlerinin merkezinde olan insan, çevresiyle sürekli etkileşim içindedir. Bu etkileşim içerisinde de genellikle hareket halindedir.

Mimari mekânları insanlar kullandıkları için mekânların biçim ve boyutları ile insan vücudunun boyutları arasında uyum olması gerekmektedir.

1. Bu uyum, sandalyede oturulduğunda, parmaklığa dayanıldığında ya da bir yere uzanıldığında ortaya çıkan statik uyumdur. 2. Bir mekâna girerken, merdivenden yukarı çıkarken, koridorda yürürken de dinamik bir uyum oluşmaktadır.

3. Diğer insanlarla olan ilişkilerde kullanılan mesafe ve kişisel alanların korunması ihtiyacının mekân içinde karşılanması derecesinden doğan uyum da göz ardı edilmemelidir.

4. Bunların yanı sıra hislerimizi ve hareketlerimizi etkileyen dokunsal, işitsel, kokusal ve ısıl özelliklerde bulunmaktadır (Resim 17), (Ching, 2004).

\subsubsection{Mekâna giriş (yaklaşım)}

Binaya ya da mekâna girmeden önce, genellikle bir yol boyunca yaklaşılır. Bu süreç içinde binanın birçok özelliğ görülmeye başlanır ve deneyimlemek için hazırlanılır. Binaya yaklaşım dik olabileceği gibi belirli bir açıda da olabilir. Bu yaklaşım "Cepheden Yaklaşım”, "Açılı Yaklaşım”, "Spiral Yaklaşım” biçiminde üçe ayrılabilir.

Cepheden Yaklaşım:

Bu yaklaşım biçimi, düz ve eksensel bir yoldan girişe doğru olmaktadır.

$\mathrm{Bu}$ yaklaşımın sonunda binanın tüm
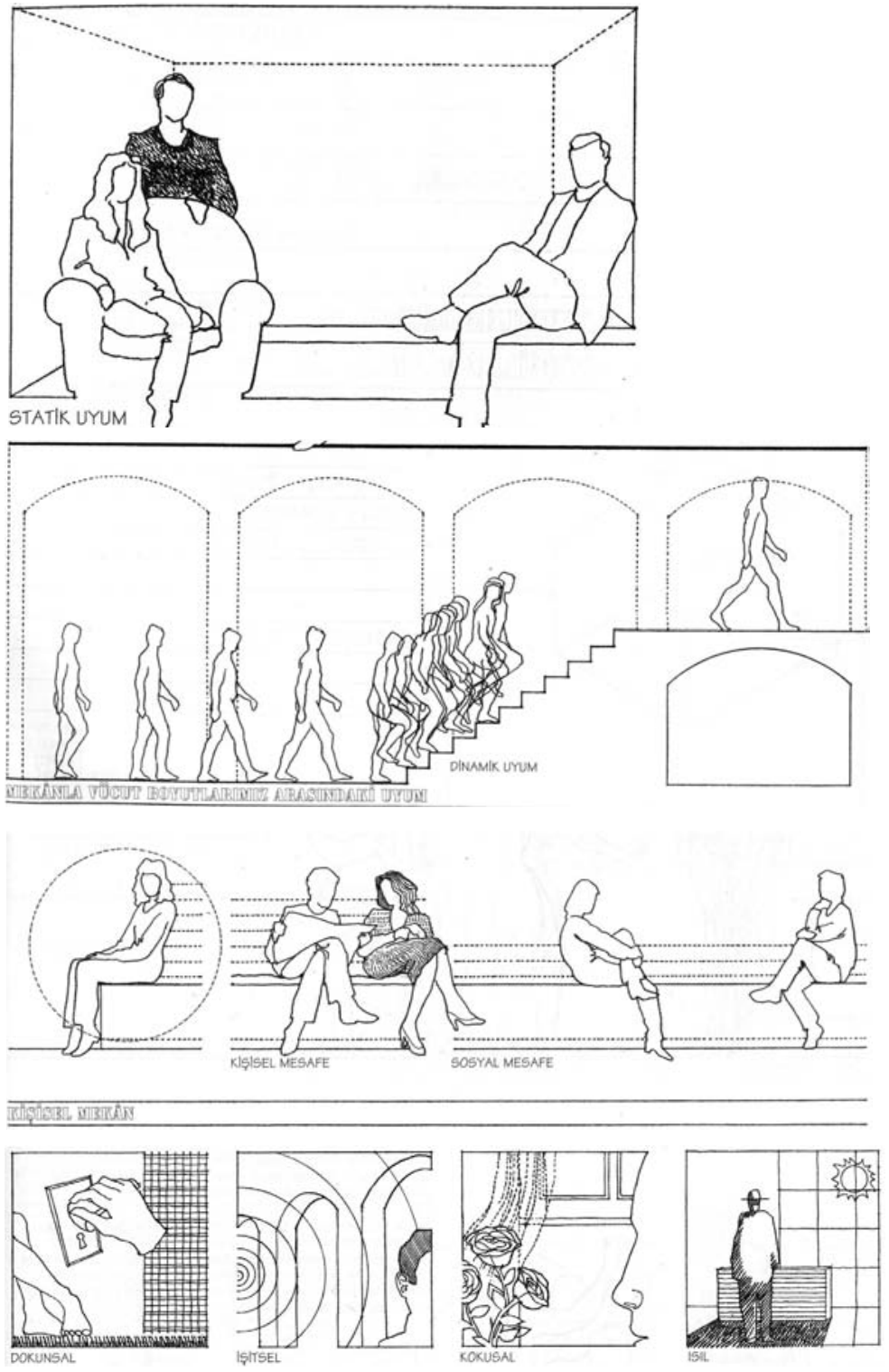

Resim: 17

yüzü ya da detaylandırılmış bir giriş görülmektedir.

Açılı Yaklaşım:

Binaya açılı yaklaşım ile binanın ön yüzünün ve biçimin perspektif etkisi artmaktadır. Farklı bakış açıları için ya da çevresel nedenlerden dolayı açılı yol, birkaç defa kırılarak girişe yönlenebilir. Binaya dar açıdan yaklaşılırken giriş belirgin olmayabilir. Bu nedenle giriște dışa doğru bir taşma yapılabilir.
Resim: 17

Mekânların biçim ve boyutları ile insan vücudunun boyutları arasinda uyum (Ching, 2004) 
Spiral yaklaşım:

Spiral yol ile yaklaşırken bina, üç boyutlu bir biçimde kavranmaktadır. Genellikle binanın girişi, yola ilk girişte ya da yol boyunca görülecek şekilde konumlandırılır (Ching, 2007).

\subsubsection{Mekânda dolaşım - sirkülasyon} İnsan ya da araçların hareket yolları çizgiseldir. Belirli bir yerden başlayan hareket gideceğimiz yere kadar çeşitli mekânlar içerisinden geçerek son bulmaktadır. Yürüme yollarının özelliği çevresindeki mekânların bağlantısına göre değişmektedir. Mekân içindeki yolların genel biçimi oluşturulurken mekân şeması da şekillenmektedir.

Ching (2007), yürüme yolu konfigürasyonunu 6 biçimde incelemektedir:

1- Çizgisel, 2- Işınsal, 3- Spiral,

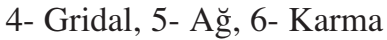

Yollar ile mekânlar arasında üç şekilde ilişki bulunmaktadır:

Mekânların Yanından Geçerek:

Bu bağlantı ile mekân bütünlüğü korunmaktadır.

Mekânların İçinden Geçerek: Bu geçiş ise mekânın içinden eksen boyunca, açılı ve mekânın bir kenarı boyunca olmaktadır. Mekânın içinde bu hareket yapılırken dinlenmek için bir düzenlemeye ihtiyaç vardir.

Bir Mekân İçinde Son Bularak: Yolun başlangıcı ve mekânın bulunduğu yerin oluşturduğu aks, yolun kendisini oluşturmaktadır. Özellikle simgesel yapıların girişi bu şekilde yapılmaktadır (Ching, 2007).

Dolaşım mekânları, sadece işlevsel bağlayıcı alanlar olarak düşünülmemeli, insanların hareketlerine, dinlenmelerine ya da manzaraya bakmalarına olanak sağlamalıdır. Merdivenler ve rampalar ise insanların bir kottan diğer bir kota ulaşımını sağlayan en önemli mimari elemanlardandır.

Mekân içinde yürüme yolu ise mekândaki eylemler ve tefrişe göre şekillenmektedir.

\subsection{Mimari mekânın aktarımında} algılayıcı hareketinin bilgisayar teknolojileri ile gerçekleştirilmesi

Bilgisayar teknolojileri, mimari mekân aktarım tekniklerine birçok yenilik getirmiştir. Burada mimari mekânın aktarımında algılayıcı hareketin bilgisayar teknolojileri ile nasıl gerçekleștirilebileceği incelenecektir. Bilgisayar ortamında yapılan aktarım teknikleri dört başlığa ayrılabilir:

- İki boyutlu çizim

- Üç boyutlu model, foto-gerçekçi görüntü (Photo-realistic image)

- Üç boyutlu animasyon

- Sanal gerçeklik (Virtual reality)

Üç boyutlu animasyon ve sanal gerçeklik uygulamalarında mekânın iki ve üç boyutlu çizimleri kullanılmaktadır. $\mathrm{Bu}$ animasyon ve sanal gerçeklik teknikleri ile tasarlanan/varolan mekânın içinde ya da çevresinde gezinti yapılabilmektedir. Konu, mimari mekânın aktarımda hareket faktörünün önemi olduğu için yukarıda bahsedilen dijital tasarım teknolojilerinden animasyon tekniği ve sanal gerçeklik üzerinde durulacaktır.

Üç Boyutlu Animasyon

Üç boyutlu modelleme yazılımlarında nokta, çizgi, düzlem ve üç boyutlu geometrilerle karmaşık modeller oluşturulmaktadır. Daha sonra renk, doku ve ışık kullanımı uygun bir biçimde yapılmaktadır. Oluşturulan üç boyutlu bir model, üç boyutlu animasyon yazılımlarında kamera hareketi ile animasyon haline dönüştürülmektedir. Ortaya çıkan bu görüntüler MOV Quick Time File, AVI File gibi formatlarda 
saklanabilmektedir. Kaydedilen bu görüntüler ise senaryoya göre kesme, yapıştırma gibi işlemler yapılarak CD-ROM, DVD-ROM, Hafıza Kartı gibi araçlara yüklenmektedir.

Mimari çizim, tasarım ve sunum amaçlı kullanılan üç boyutlu modelleme, canlandırma ve kaplama yazılımlarından biri olan 3ds MAX ve eş programlardaki kameranın kullanım şekilleri sinema sanatında kullanılan kameraya benzerlik göstermektedir. Bunun yanı sıra dijital ortamda kullanılan bu kamera, sinemadaki gerçek kameranın hareket olanaklarından daha fazlasına sahiptir.

Resim 18'de 3ds MAX 7 versiyonunun arayüzü görülmektedir. Ekranda görülen, gerçek kameradaki gibi hedef özelliği olan bir kameradır (target camera). Gerçek kameranın ögeleri olan kamera, hedef, kameranın hareket doğrultusu, kameranın görüş doğrultusu bu programda bulunmaktadir.

Günümüzde bir çok modelleme programı ile sabit görüntüde model oluşturulmaktadır. Kameranın rastgele hareket ettirilmesiyle tasarım geliştirilmektedir. Buna bağlı olarak filmlerdeki kamera hareketleri kullanılarak tasarım daha fazla geliştirilebilir. Bunu yapmak için tasarlanan objenin modeli oluşturup etrafında dolaşılarak istenilen etkinin verilip verilmediği kontrol edilir ve sonra tekrar tasarıma geçilebilir. Kamera hareketleri ile tasarımı geliştirmenin bir başka yolu ise hareketli bir düzlemde model oluşturmaktır. $\mathrm{Bu}$ yöntem ile tasarım yapmak şimdilik zor görünse de gelişen teknolojilerle bunun mümkün olacağı görülmektedir.

Animasyon ile istenilen görünüşler ve etki elde edilmektedir. Mimari mekânı kuş bakışı, insan göz hizası ya da istenilen her hangi bir yükseklikten rahatlıkla gösterebilmekte; bilgisayar animasyonu ile önemli tarihi mekânlar etkileyici bir biçimde izleyiciye aktarılabilmektedir (Özcan, 1993): Örneğin Osaka Üniversitesi’nde, T. Sasada, İpek

Resim: 18

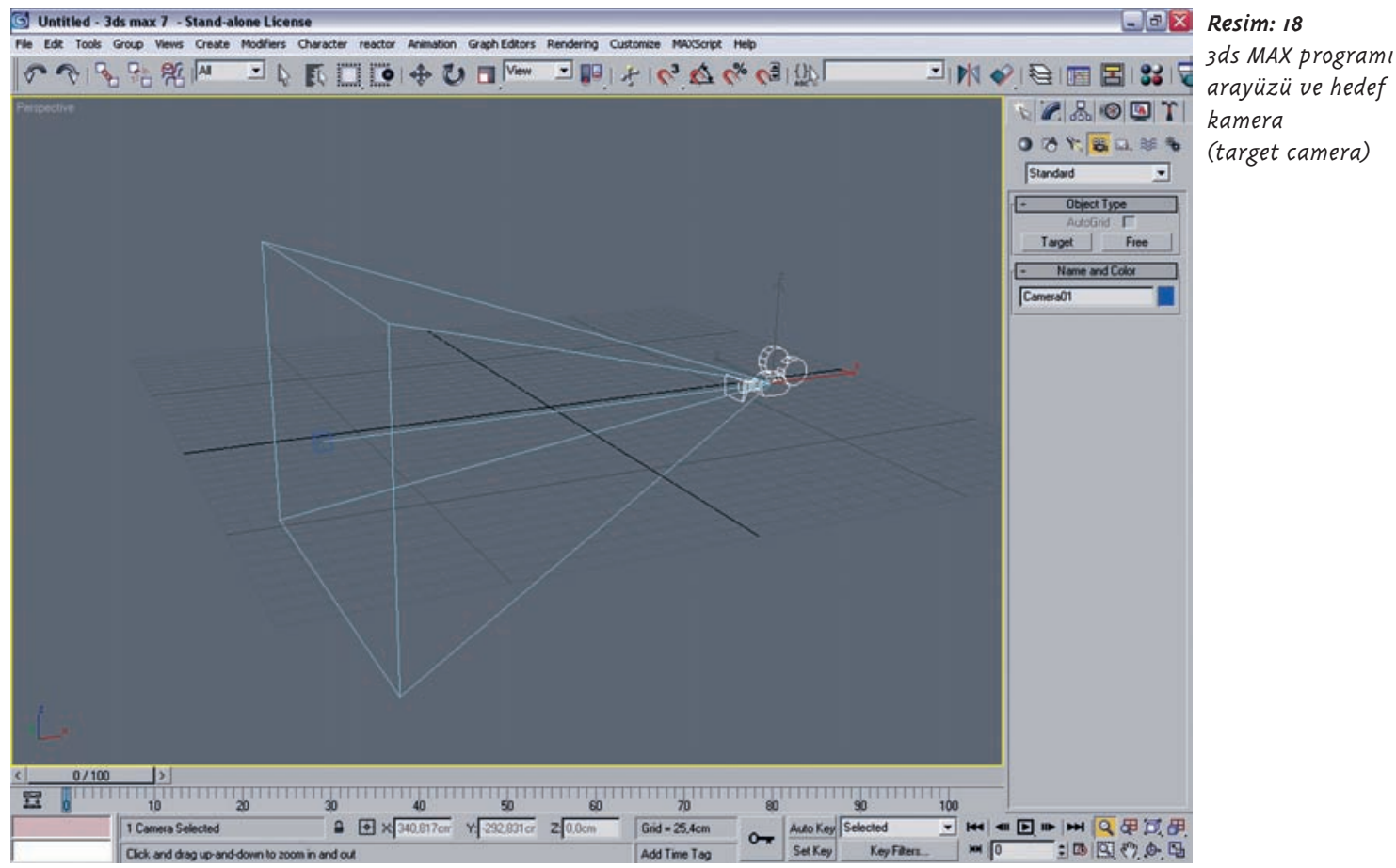

94 Sayı 7, Mayıs 2009 


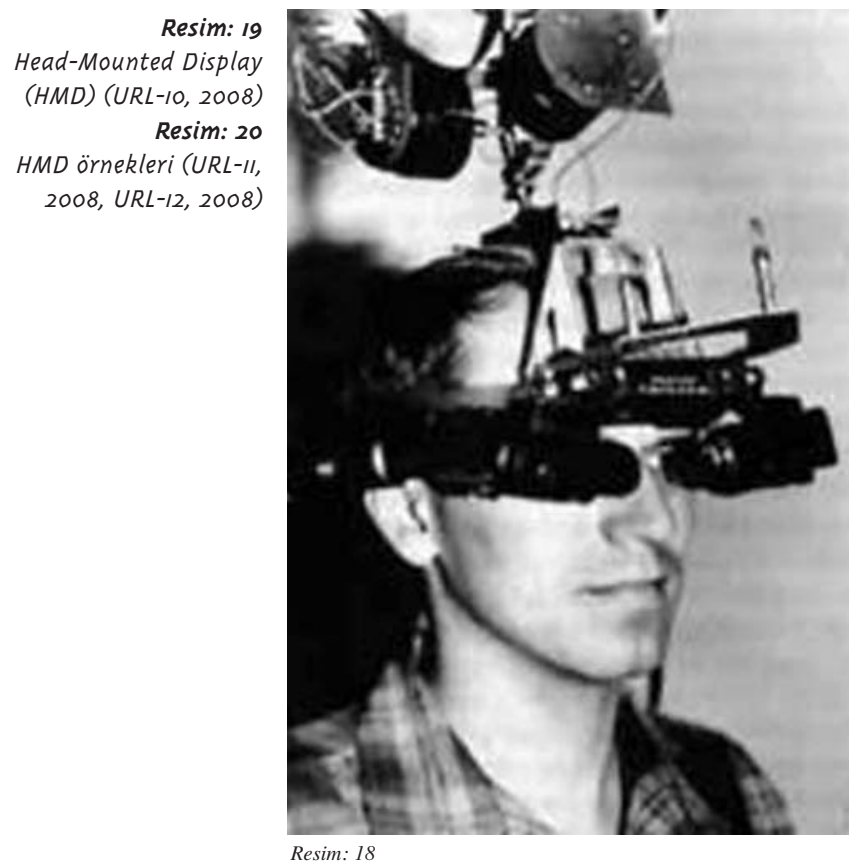

Yolu üzerinde kayıp bir şehir olan Lau-Lui'nun animasyonunu yapmış; Fransız Devriminin 200. yüzyılı için Ex-Machina Fransız firması, Paris'in 18. yüzyıldaki durumunu gösteren bir animasyon hazırlamış; Le Corbusier'nin Ronchamp Şapeli'nin ışık tasarımının vurgulanması için bir bilgisayar animasyonu yapılmıştır.

Moğol İmparatorluğu'nun başkenti; Panthenon ve Çin Seddi'nin bilgisayar animasyonları yapılmıştır.
Sanal gerçeklik (Virtual reality -VR): Bilgisayar teknolojilerinin geldiği noktalardan en önemlisi "sanal gerçeklik"tir (virtual reality). Sanal gerçeklik, bilgisayar teknolojileri ve bir çok cihaz ile oluşturulan dinamik bir ortamda kullanıcıya gerçekmiş hissi verilen bir sistemdir. Sanal gerçeklik, insanın duyularına gerçeğe çok yakın koşullar sağlayarak hitap etmeye çalışmaktadır. Bunu, özel gözlükler, eldivenler, hareket algılayıcıları, kabinler, çeşitli yansıtma ve bilgi girişi yapılan araçlarla sağlamaktadır. Sanal gerçeklik sayesinde kullanıcı, bir mekâna gitmeden gezebilmekte ve etkileşim içinde bulunabilmektedir. Sanal gerçeklik sisteminde kullanıcı, üç boyutlu bir veri setinin içine girmektedir. Sanal gerçeklik teknolojisindeki gereksinimler şöyle siralanabilir:

- HMD (Head-Mounted Display) adı verilen gözlük ve kulaklıktan oluşan kasket: Bir çok gelişmiş HMD çeşidi bulunmaktadır: $\mathrm{Bu}$ cihaz sayesinde kullanıcı görüntüyü üç boyutlu olarak algilamaktadır (Resim 19-20).

- Data eldiven ya da 3D fare: sanal mekân içinde, sanal objeleri tutmaya, onları
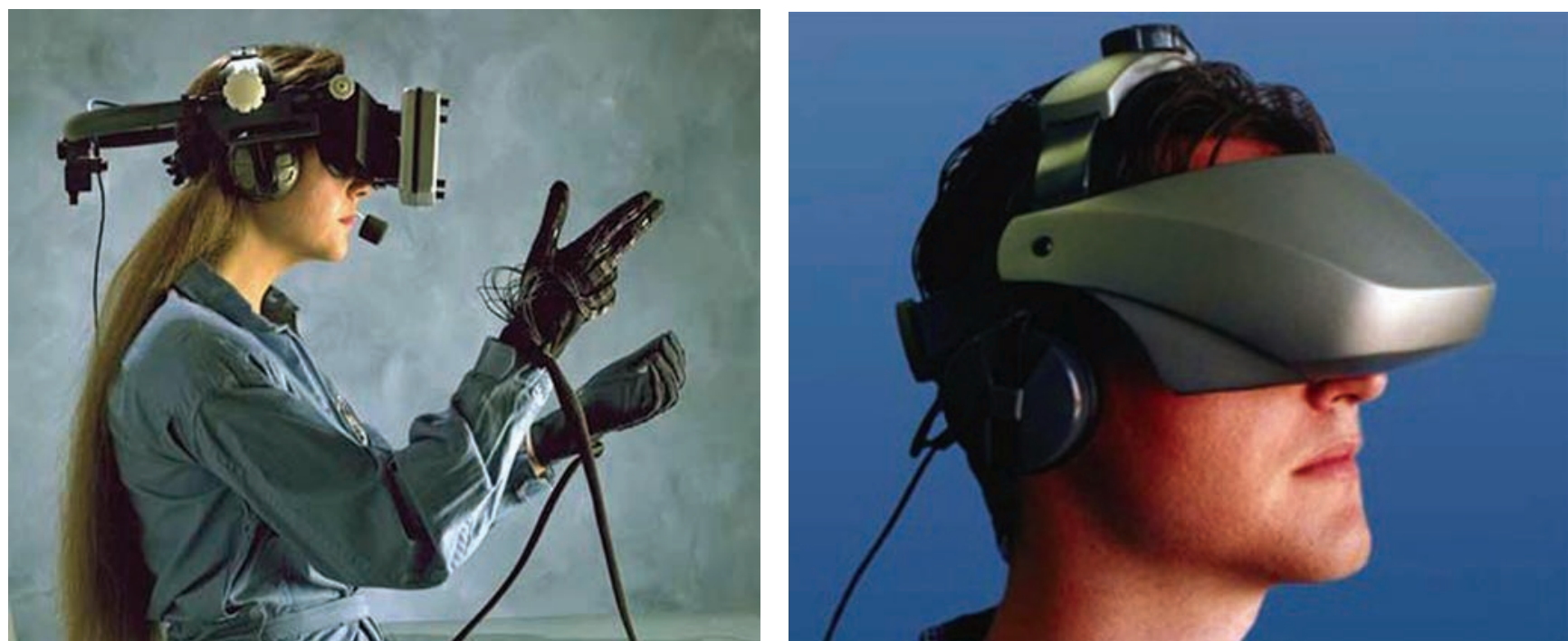
hareket ettirmeye yaramaktadır. Aynı zamanda komuta dayalı gereksinimler de bu eldivenle sağlanmaktadır.

- Hareket platformu: yürüme bantı, sabit bisiklet, araba direksiyonu gibi hareketli
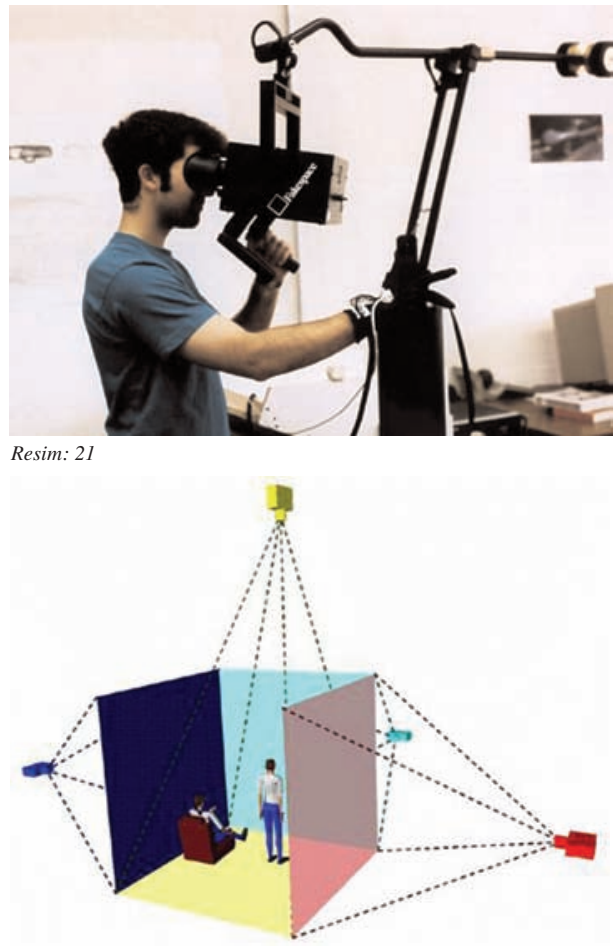

Resim: 22

platformlar sayesinde kullanıcı, o mekân içinde yürüme, koşma, sürme gibi hareketler yapabilmektedir.

- Güçlü bir bilgisayar ve özel yazılımlar.

- Sanal çevrenin görselleştirilmesi: Resim 23 'de gerçeklik etkisini artırmak için döşemeye, duvara ve tavana görüntüler yansıtılması işlemi görülmektedir.

Sanal gerçeklik fikri ilk kez Amerikalı Ivan Sutherland tarafından 1960 yılında ortaya atılmıştır. 1965 yılında Sutherland, interaktif grafikler, koku, tat ve ses gibi bir çok unsurun sağlandığg yapay bir ortam önerisinde bulunmuştur. Daha sonra da kullanıcının başına takılan, stereo görüntü ile çalışan bir cihaz (Head-Mounted Display) (Resim 20) yaratmıştır (URL-10, 2008). 1990’l1 y1llarda Head-Mounted Display

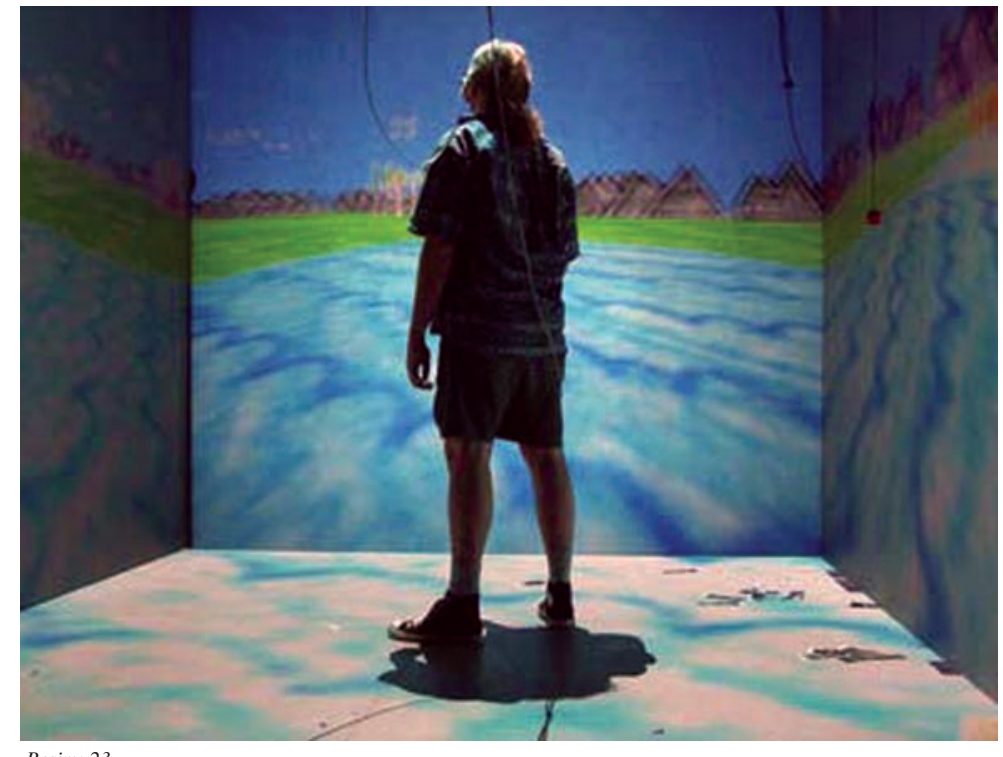

Resim: 23

(HMD) sisteminin geliştirilmesi sonucu

BOOM (Binocular Omni - Orientation Monitor)

ve CAVE (Cave Automatic Virtual Environment) gibi sistemler ortaya çıkmıştır. BOOM (Resim 21) aracinda bir kol ve üzerine yerleştirilmiş küçük bir monitör bulunmaktadir. CAVE (Resim 22-23) sistemlerinde ise kullanıcıya monitör, kask, kablo gibi kısıtlayıcı araçlardan bağımsız bir ortam sunulmaktadır. Kullanıcı görüntünün içinde yer almaktadir (URL-13, 2008).

\section{Sonuç}

Bu çalışmada mimari mekânın aktarımında algılayıcı hareketinin önemi günümüz teknolojik koşulları ile birlikte ortaya konmuştur.

Algılayıcının hareketi, mimarinin oluşumuyla birlikte etkili bir faktör olmasına karşın ciddi boyutta ele alınması 20. yüzyıl başlarına rastlamaktadır. Birçok mimar ve mimarlık kuramcısı, mekânın tam olarak algılanması için kullanıcının mekân içinde gezmesi gerektiğini savunmaktadır. Bu çalışmada, bu fikirden yola çıkarak mekânın aktarımında algılayıcı hareketinin
Resim: 21

BOOM (URL-13, 2008)

Resim: 22

CAVE sistemi (URL-13, 2008)

Resim: 23

CAVE (URL-14, 2008) Sanal gerçeklik, kullanıcıya bir fok olanaklar sunmasının yaninda pahalı bir sistemdir. sistemden tam anlamiyla yararlanabilmek için son derece pahalı cihazlar kullanılması gerekebilir. 
olması gerektiği savunulmaktadır. Algılayıcı hareketi sadece bir yerden bir yere gitmek olarak değil, aynı zamanda insanın bulunduğu yerde göz, baş ve bedenin yaptığı hareketler olarak tanımlanmaktadır. İnsan bu hareketleri yaparak çevresindeki detayları algılamaya başlar ve elemanlar arasındaki ilişkileri daha iyi kavrar. Mekânın içinden ya da yanından geçmek, mekânı ziyaret etmek mekâna farklı gözlerle bakılmasını sağlamaktadır.

Mimari mekânda algılayıcı hareketleri birçok şekilde olmaktadır. Bunlar; mekâna giriş (cepheden yaklaşım, açılı yaklaşım, spiral yaklaşım) ve mekânda dolaşım - sirkülasyon biçimindedir. İnsanın bulunduğu yerden yaptığı, beden, baş ve göz hareketleri de bulunmaktadır.

İnsanın mimari mekân içindeki bu hareketlerinin mimari mekânın aktarım tekniklerinde kullanımı günümüz bilgisayar teknolojileri ile olanaklı hale gelmiştir. Bunun en yaygın kullanımı iki şekilde yapılmaktadır: üç boyutlu animasyon ve sanal gerçeklik.

Mimari mekânın aktarımında, bilgisayar teknolojilerinin en yaygın olarak kullanıldığı aktarım tekniklerinden üç boyutlu bilgisayar animasyonlarının birçok avantajı bulunmaktadır:

- Özellikle tarihi mekânlarla ilgili ayrıntılı gözlem yapılmasını olanaklı kılmaktadır. Böylece o yapıların hangi dönemi nasıl yansıttığı daha iyi kavranabilmektedir. - Varolan ya da tasarlanan mekânın animasyonu istenilen yerde durdurularak, geri sardırılarak, yavaş ya da hızlı gösterilerek daha ayrıntılı gözlem yapılabilmektedir.

- Bilgisayar animasyonu ile bir mimari mekân, yaşayan insanın gözüyle aktarılabilmekte; böylece mekânın kullanıcının gözüyle nasıl algılandığ sunulabilmektedir.
- Animasyonu izleyen kişi isterse üç boyutlu model üzerinde hareketleri kendi kontrol ederek mekânı özgürce gezebilmektedir.

- Animasyonun en önemli özelliği olan hareket faktörü sayesinde iç ve dış mekân geçişinin ifadesi daha güçlü olabilmektedir.

Mimari mekânın aktarımında algılayıcı hareketinin önemi bilgisayar teknolojilerinin kullanımının yaygınlaşması ile ön plana çıkmıştır. Algılayıcı hareketinin mekân tasarımlarına girdi olarak eklenmesiyle, gerçek mekânda oluşacak alg1 ve bunun yansımaları kurgulanabilecek; böylece tasarlanan mekandaki olumsuz özellikler bertaraf edilebilecektir. Sonuç olarak kullanıcının mimari mekânda görsel algılama sırasında yaptığı hareketler, mekânın aktarımında büyük önem taşımaktadır. Bunun da günümüzde üç boyutlu animasyon kullanımının yaygınlaştırılması ve etkin bir biçimde kullanılması ile mümkün olabileceği görülmektedir. Bunun için de mimarların, iç mimarların ve bilgisayar yazılımcılarının işbirliği içinde çalışmalarını sürdürmeleri yararlı olacaktır. $\mathrm{Bu}$, üniversitelerin, meslek odalarının, mimarların ve iç mimarların dikkate alması gerekli bir konu olarak görülmektedir • 


\section{KAYNAKÇA}

Atkinson, R., Atkinson R. C., Hilgard, E.R., 1995. Psikolojiye Giriş, (Çev., K. Atakay), Sosyal Yayınlar, İstanbul.

Baymur, F.,1994. Genel Psikoloji, İnkılap ve Aka Kitabevi, İstanbul.

Benton, T., 1997. Representing Le Corbusier, Film, Exhibition, Multimedia, Cinema and Architecture, Ed: François Pènz and Maureen Thomas, British Film Institude, London.

Berger, A. A., 1998. Seeing is Believing-An Introduction to Visual Communication, Mayfield Publishing Company, California

Ching, F. D. K., 2004. İç Mekân Tasarımı, Yapı Yayın, İstanbul.

Ching, F. D. K., 2007. Mimarlık: Biçim, Mekân ve Düzen, (Çev., S. Lökçe), YEM Yayın, İstanbul.

Cullen, G., 1961. Townscape, The Architectural Press, London.

Dal Co, F., Forster, K.W., 1998. Frank O.Gehry, The Complete Works, The Monacelli Press, New York.

Erkman, U., 1973. Mimarîde Etki ve Görsel İdrak İlişkileri, yayımlanmamış doktora tezi, İstanbul Teknik Üniversitesi Mimarlık Fakültesi Baskı Atölyesi, İstanbul.

Hasol, D., 1998. Ansiklopedik Mimarlık Sözlüğü, Geliştirilmiş 7.Baskı, YEM Yayın, İstanbul.

Hoogstad, J., 1990. Space-Time-Motion, Gravenhage, Netherlands.

İnceoğlu, N., 1995. Düşünme ve Anlatım Aracı Olarak Eskizler, Helikon Yayınları, İstanbul.

Lang, J., 1987. Creating Architectural Theory, The Role of the Behavioral Sciences in Environmental Design, Van Nostrand Reinhold, New York.

Lefebvre, H., 1991. The Production of Space, translated by Donald Nicholson-Smith, Basil Blackwell Ltd, Oxford.

Meiss, P., 1990. Elements of Architecture, E \& FN Spon, An Imprint of Chapman \& Hall, London.

Morgan, C.T., 1995. Psikolojiye Giriş, (Çev., H. Arıcı), Meteksan, Ankara.

Norberg-Schulz, C., 1971. Existance, Space and Architecture, Studio Vista, Londra.

Özcan, O., 1993. Tarihi Mekânlar İçin Bir Hypermedya Sistemi Önerisi, yayımlanmamıș doktora tezi, Mimar Sinan Üniversitesi, Fen Bilimleri Enstitüsü, İstanbul.

Panero, J., Zelnick, M., 1979. Human Dimension \& Interior Space, Business Media, Inc., New York, USA.

Pevsner, N., 1963. An Outline of European Architecture, Introduction, Penguin Books, Harmondsworth, Middlesex, England.

Porter, T., 1979. How Architects Visualise, Cassel, London.

Porter, T., 1997. The Architect's Eye: Visualization and Depiction of Space in Architecture, E\&FN Spon, London.

Sekuler, R.; Blake, R., 1994. Perception, New York, London, McGraw-Hill.

Tanyeli, U., 2001. Temsiliyet Nesnesinin Temsili Sanalın Sanallıkla İfadesi, Sinema ve Mimarlık Dosyası, Arredamento Mimarlik, 11, 66.

Us, F., 2000. Özel Çalışması
Vitruvius, 1990. De architectura (Mimarlık Üzerine On Kitap), (Çev., S. Güven), Şevki Vanlı Mimarlık Vakfı Yayınları, İstanbul.

Yürekli, K.F., 1977. Çevre Görsel Değerlendirmesine İlişkin Bir Yöntem Araștırması, yayımlanmamış doktora tezi, İ.T.Ü. Mimarlık Fakültesi Baskı Atölyesi, İstanbul.

Zevi, B., 1993. Architecture as Space, Da Capo Press, New York.

\section{INTERNET}

URL-1, http://www.tdk.gov.tr/, 2008

URL-2,

http://www.miniaturk.com.tr/MiniaturkRehber.asp?eser=17, 2008

URL-3, http://faculty.evansville.edu/r129/art105/img/corbusier_savoye.jpg

URL-4, http://ebertfest.com/seven/playtime003.jpg, 2008

URL-5, http://figure-ground.com/villa_savoye/0010/, 2008

URL-6, http://figure-ground.com/villa_savoye/0009/, 2008

URL-7, http://www.stevenholl.com/project-

detail.php?type $=$ houses $\&$ id $=26 \&$ page $=1,2008$

URL-8, http://www.stevenholl.com/project-

detail.php?type $=$ museums $\&$ id $=24 \&$ page $=1,2008$

URL-9, http://sonerorhan.tripod.com/Tasit_ergonomi.pdf,

2008

URL-10, http://www.medienkunstnetz.de/works/head-

mounted-display/, 2008

URL-11, http://electronics.howstuffworks.com/virtual-reality7.htm, 2008

URL-12, http://www.vrealities.com/5dt.html, 2008

URL-13, http://www-vrl.umich.edu/intro/, 2008

URL-14 http://electronics.howstuffworks.com/virtual-reali-

ty.htm, 2008 